L. V. Batyuk ${ }^{1}, \mathrm{PhD}$, docent,

N. M. Kizilova ${ }^{2}$, DSc, prof.

\section{Maghetohydrodynamic flows of micro/nano fluids through thin capillaries}

1 V.N. Karazin Kharkov National University, 61022, Kharkov, Svobody sq., 4,

2 V.N. Karazin Kharkov National University, 61022, Kharkov, Svobody sq., 4, e-mail:n.kizilova@gmail.com liliyabatyuk24@gmail.com
Батюк Л. В. ${ }^{1}$, к. ф.-м. н., доцент, Кізілова Н. М. ${ }^{2}$, д. ф.-м. н., проф.

\section{Магнітогідродинамічні течії мікро/нано рідин по тонких капілярах}

\author{
1 Харківський національний медичний \\ університет, 61022, м. Харків, пл. Свободи, 2, \\ Харківський національний університет \\ ім. В.Н. Каразіна, 61022, м. Харків, пл. Свободи, \\ 4 , \\ e-mail:n.kizilova@gmail.com \\ liliyabatyuk24@gmail.com
}

Steady magnetohydrodynamic (MHD) flows of suspensions of conducting micro/nanoparticles through a thin tube of a circular cross-section in a transverse constant magnetic field driven by a constant pressure drops at the ends of the tube is studied. The governing MHD system of equations for a viscous incompressible micro/nanofluid in the non-induction approximation is solved with the second order velocity slip boundary condition at the wall of the tube. The material parameters of the fluid are considered as nonlinear functions of the particle concentration according to the mixture models of suspensions and electric conductivity theory. The velocity field, pressure, electric current and magnetic field have been computed as series expansions. The influence of two non-dimensional slip coefficients of the flow rate and wall shear stress is studied. Optimal concentrations of the micro/nanoparticles in the suspensions have been computed from the minimum entropy production condition for different slip conditions, material parameters, magnetic fields and flow regimes (Reynolds and Hartmann numbers).

Key Words: Microfluids, Nanofluids, Magnetohydrodynamics, Steady flows.

Досліджуються стаціонарні магнітогідродинамічні (МГД) течії суспензій електропровідних мікро/наночастинок крізь тонку трубку кругового перерізу в поперечному постійному магнітному полі за рахунок постійного перепаду тиску на кіниях трубки. Система рівнянь МГД-течії в'язкої нестисливої мікро/нанорідини в безіндукиійному наближенні розв'язується за наявності для швидкості граничних умов прослизання другого порядку на стіниі трубки. Матеріальні параметри рідини розглядаються як нелінійні функції концентрації частинок відповідно до моделей сумішей та теорії електропровідності. Вираження для поля швидкості, тиску, електричного струму та магнітного поля отримані у вигляді розкладень у ряди. Вивчено вплив двох безрозмірних коефічієнтів прослизання на швидкість течії та напруження зсуву на стінці. Оптимальні конщентрації мікро / наночастинок у суспензіях обчислені з умови мінімуму виробництвва ентропії в каналі для різних умов прослизання, параметрів матеріалу, магнітних полів та режимів течї̈ (числа Рейнольдса та Гартмана).

Ключові слова: Мікрорідини, Нанорідини, Магнітна гідродинаміка, Стаціонарні течії.

Статтю представив д.ф.-м.н., проф. Жук Я.О

1. Introduction. Significant success in material sciences and electronics, medicine and biology, chemical and power engineering is tightly connected with novel micro- and nanotechnology that had been developed during the last decades. Precise 'molecular' assembling of nanocomposites, coatings, molecular motors, and other nanoscale analogies of macroscopic materials and machines allow elaboration of microgears, molecular motors, and microelectromechanical systems (MEMS) for detailed manipulations with nanoparticles, fibers, biological cells and extracellular materials [1]. 
Suspensions of micro or nanoparticles (microfluids and nanofluids) possess unique physical, chemical and biological properties due to high surface-tovolume ratio for the small particles. Mictofluidic and nanofluidic systems are widely used in modern technologies, biology and medicine for mixing or separation of fluids, water purification and desalinization, heating of small volumes of materials, cooling of the MEMS, drug delivery to the target tissues, medical diagnostics with lab-on-a-chip and other promising technologies [2].

The micro- and nanofluids used in such systems have complex mechanical, thermal, electromagnetic and optic properties which depend on the concentration, shape, size and material parameters of the micro/nanoparticles. Therefore, even lowintensity external electric or magnetic fields may significantly influence the flows of micro/nanofluids through the tubes or ducts [3]. Weak electric and magnetic fields generated by the heart and muscle contractions, brain and cell activity could influence the drug delivery to tumors inside the organisms [4]. Electromagnetic properties of the blood cells used for early diagnosis of cancer [5] may also influence the measurement results and, therefore, the accuracy of the diagnostic test.

In the moving suspensions the FahraeusLindquist effect produces a low viscosity boundary layer free of the particles (apparent slip layer, ASL) that accelerates the flow [5]. In the suspensions of microparticles $(1<\mathrm{d}<100 \mu \mathrm{m})$ or nanoparticles $(1<\mathrm{d}<100 v \mathrm{~m})$ the Knudsen layer produced by the complete or partial diffusion scatter of the particles at the wall roughness appears and influences the flow velocity and wall shear stress [6]. Its thickness is compatible to the mean free path $\lambda$ of the particles that is much smaller than the thickness of the ASL [7]. As it was shown in numerous experiments with the flows in micro and nanotubes, the measured volumetric rates and wall shear stress differ in 5-60\% from the corresponding values computed on the classical Navier-Stokes equations for convenient incompressible fluids $[2,6,7]$. The main reasons of the differences are velocity slip and temperature jump boundary conditions (BC) at the solid walls and complex dependencies of the material parameters on the particle concentration $\varphi$ and other properties. The heat conduction, electric and other physical parameters of the micro/nanosuspensions are increasing functions of $\varphi$, while the fluid viscosity and energy loss for viscous dissipation also increases with $\varphi$. Therefore, the solution of the optimization problem for the values $\varphi$ when the physical properties are high enough and the viscous dissipation is reasonably low is of a great importance for micro/nanofluid dynamics applications.
In this paper the influence of the $\mathrm{BC}$ and suspension parameters on the MHD flow and the field strength is studied. The optimization problem for the particle concentration at different material parameters and flow conditions is solved based on the minimum entropy production approach.

2. Problem formulation. Steady flow $(\partial / \partial t=0$, $\overrightarrow{\mathrm{v}}=\mathrm{V} \overrightarrow{\mathrm{e}}_{\mathrm{x}}, \overrightarrow{\mathrm{B}}=\mathrm{B} \overrightarrow{\mathrm{e}}_{\mathrm{x}}+\mathrm{B}_{0} \overrightarrow{\mathrm{e}}_{\mathrm{z}}$, cylindrical coordinates) of a uniform suspension of the micro or nanoparticles of diameters $d_{p}$ with concentration $\varphi$ in an incompressible Newtonian fluid through a thin tube of a circular cross-section with radius $\mathrm{R}$ and wall thickness $\mathrm{h}<\mathrm{R}$ in a transverse external magnetic field $\overrightarrow{\mathrm{B}}_{0}=\mathrm{B}_{0} \overrightarrow{\mathrm{e}}_{\mathrm{z}}, \mathrm{B}_{0}=$ const and the pressure drop $\Delta \mathrm{P}=\mathrm{P}^{+}-\mathrm{P}^{-}=$const (Fig. 1 ) is considered.

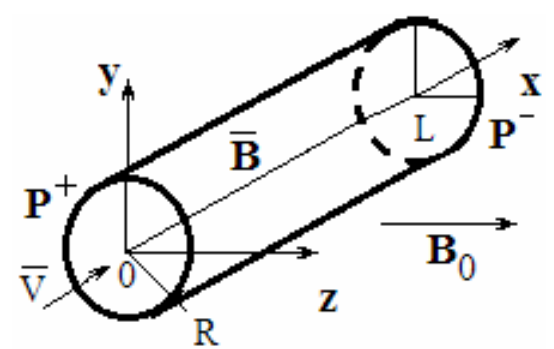

Рис.1. Scheme of the flow geometry.

The flow is governed by the following system of equations in the non-induction approximation [8]

$$
\begin{gathered}
\frac{\partial \mathrm{V}}{\partial \mathrm{x}}=0, \quad \mu_{\mathrm{eff}} \Delta \mathrm{V}+\frac{1}{4 \pi} \overrightarrow{\mathrm{B}}_{0} \cdot \nabla \mathrm{B}=\Delta \mathrm{P} / \mathrm{L}, \\
v_{\mathrm{m}} \Delta \mathrm{B}+\overrightarrow{\mathrm{B}}_{0} \cdot \nabla \mathrm{V}=0,
\end{gathered}
$$

where $v_{\mathrm{m}}=\mathrm{c}^{2} /\left(4 \pi \sigma_{\text {eff }}\right)$ is the magnetic viscosity, $\overrightarrow{\mathrm{B}}$ is the field inside the tube.

The $\mathrm{BC}$ for (1)-(2) are the 2-nd order velocity slip condition at the wall and the flow symmetry at the axis $[6,7]$

$$
\begin{aligned}
& \mathrm{r}=0: \frac{\partial \mathrm{V}}{\partial \mathrm{r}}=0, \\
& \mathrm{r}=\mathrm{R}: \mathrm{V}=\alpha_{1} \mathrm{Kn} \frac{\partial \mathrm{V}}{\partial \mathrm{r}}+\alpha_{2} \mathrm{Kn}^{2} \frac{\partial^{2} \mathrm{~V}}{\partial \mathrm{r}^{2}}
\end{aligned}
$$

where $\mathrm{Kn}=\lambda / \mathrm{R}$ is the Knudsen number, $\alpha_{1,2}$ are constants (according to [6], $\alpha_{1} \in[1 ; 1.15]$, $\left.\alpha_{2} \in[-0.5 ; 1.31]\right), \alpha_{2}=0$ for the microfluids.

The second $\mathrm{BC}$ at the wall for (1)-(2) is [8]

$$
\begin{aligned}
& r=R: \frac{\partial B}{\partial r}=0 \text { for ideal conducting wall, } \\
& r=R: B=\frac{2 \pi j}{c} \text { for ideal insulating wall, }
\end{aligned}
$$

where $\vec{j}=\sigma_{\text {eff }} \vec{V} \times \vec{B} / c$ is the electric current, $\sigma_{w}$ is the wall conductivity.

Solution of (1)-(3), (5), (6) for the velocity nonslip $\mathrm{BC}$ has been obtained in the approximations of 
large and small Hartmann numbers, walls with zero and small conductivity, thin wall with arbitrary conductivity and the wall with finite thickness and conductivity $[8,9]$.

As it is well-known from the general MHD theory, with two new parameters introduced as

$$
\mathrm{V}_{1,2}=\left(\mathrm{V} \pm \frac{\mathrm{cB} / 4 \pi \mp \mathrm{zc} \Delta \mathrm{P} / \mathrm{B}_{0} \mathrm{~L}}{\sqrt{\sigma_{\text {eff }} \mu_{\mathrm{eff}}}}\right) \exp ( \pm \mathrm{mz}),
$$

where $\mathrm{m}=\sqrt{\frac{\sigma_{\text {eff }}}{\mu_{\text {eff }}}} \frac{\mathrm{B}_{0}}{2 \mathrm{c}}$, the system (1)-(2) gives

second-order equations

$$
\Delta \mathrm{V}_{1,2}-\mathrm{m}^{2} \mathrm{~V}_{1,2}=0
$$

with boundary conditions (3) and

$$
\mathrm{V}_{1}+\mathrm{V}_{2}=\mathrm{C}_{1} \mathrm{Kn} \frac{\partial\left(\mathrm{V}_{1}+\mathrm{V}_{2}\right)}{\partial \mathrm{r}}+\mathrm{C}_{2} \mathrm{Kn}^{2} \frac{\partial^{2}\left(\mathrm{~V}_{1}+\mathrm{V}_{2}\right)}{\partial \mathrm{r}^{2}}
$$

and $\frac{\partial\left(\mathrm{V}_{1}-\mathrm{V}_{2}\right)}{\partial \mathrm{r}}+\frac{\sigma_{\text {eff }}}{\sigma_{\mathrm{w}} \mathrm{h}}\left(\mathrm{V}_{1}-\mathrm{V}_{2}\right)=0$

or $\quad V_{1}-V_{2}=2 \pi j / c$,

instead of the conditions (4)-(6) accordingly.

The effective density $\rho_{\text {eff }}$, electric conductivity $\sigma_{\text {eff }}$ and dynamic viscosity $\mu_{\text {eff }}$ of the suspension can be introduced by one of the formulae accepted for mixtures and corrected for the micro/nanofluids in the experiments $[2,3,6,7]$

$$
\begin{aligned}
& \rho_{\text {eff }}=\rho_{\mathrm{p}} \varphi+\rho_{\mathrm{f}}(1-\varphi), \\
& \sigma_{\text {eff }}=\sigma_{\mathrm{f}}\left(1+\frac{3 \varphi\left(\sigma_{\mathrm{p}}-\sigma_{\mathrm{f}}\right)}{\sigma_{\mathrm{p}}+2 \sigma_{\mathrm{f}}+\varphi\left(\sigma_{\mathrm{f}}-\sigma_{\mathrm{p}}\right)}\right), \\
& \mu_{\mathrm{eff}}=\mu_{\mathrm{f}}(1-\varphi)^{-2.5},
\end{aligned}
$$

where the subscripts $(.)_{\mathrm{p}}$ and $(.)_{\mathrm{f}}$ stand for the particles and basic fluid accordingly.

3. Problem solution. In the non-dimensional variables $\overline{\mathrm{r}}=\mathrm{r} / \mathrm{R}, \quad \overline{\mathrm{x}}=\mathrm{x} / \mathrm{R}, \quad \overline{\mathrm{B}}=\mathrm{B} /\left(\mathrm{V}_{0} \sqrt{\sigma_{\mathrm{f}} \mu_{\mathrm{f}}}\right)$, $\overline{\mathrm{V}}=\mathrm{V} / \mathrm{V}_{0}$, where $\mathrm{V}_{0}$ is the characteristic velocity the solution $\mathrm{V}_{1,2}(\mathrm{r}, \vartheta)$ of (8)-(10) can be found by using the technique of separation of variables in the general form

$$
\overline{\mathrm{V}}_{1,2}=\sum_{\mathrm{n}=0}^{\infty} \mathrm{I}_{\mathrm{n}}(\mathrm{H} \overline{\mathrm{r}})\left(\mathrm{C}_{\mathrm{n}}^{1,2} \cos (\mathrm{n} \vartheta)+\mathrm{D}_{\mathrm{n}}^{1,2} \sin (\mathrm{n} \vartheta)\right),
$$

where $\mathrm{H}=\mathrm{B}_{0} \mathrm{R} \sqrt{\sigma_{\mathrm{f}} / \mu_{\mathrm{f}}}$ is the Hartmann number, $I_{n}(y)$ are modified Bessel functions of order $n$.

The magnetic field in the wall has the form [9]

$$
\overline{\mathrm{B}}_{\mathrm{w}}=\mathrm{A}_{0}+\mathrm{B}_{0} \ln (\overline{\mathrm{r}})+\sum_{\mathrm{n}=0}^{\infty}\left(\mathrm{A}_{\mathrm{n}} \overline{\mathrm{r}}^{\mathrm{n}}+\mathrm{B}_{\mathrm{n}} \overline{\mathrm{r}}^{-\mathrm{n}}\right) \cos (\mathrm{n} \vartheta),
$$

and the field continuity equations

$$
\overline{\mathrm{r}}=1: \overline{\mathrm{B}}=\overline{\mathrm{B}}_{\mathrm{w}}, \frac{1}{\sigma_{\text {eff }}} \frac{\partial \overline{\mathrm{B}}}{\partial \overline{\mathrm{r}}}=\frac{1}{\sigma_{\mathrm{w}}} \frac{\partial \overline{\mathrm{B}}_{\mathrm{w}}}{\partial \overline{\mathrm{r}}}
$$

where $\sigma_{\mathrm{w}}$ is the wall conductivity are satisfied.

Unknown constants $\mathrm{C}_{\mathrm{n}}^{1,2}, \mathrm{D}_{\mathrm{n}}^{1,2}, \mathrm{~A}_{\mathrm{n}}, \mathrm{A}_{0}, \mathrm{~B}_{0}$ have been found from the algebraic system of equations. The complex expressions for them are not presented due to brevity.

Numerical computations have been carried out for the material parameters taken for blood as a microfluid [4,5] and some technical diluted nanofluids of rigid nanoparticles [7]. The most interesting results are presented in Fig.2-5. Entropy generation due to viscous dissipation in the flow has been computed as a function of the concentration $\varphi$ in the form:

$$
\dot{S}=\int_{0}^{1} d \bar{x} \int_{0}^{2 \pi} d \theta \int_{0}^{1} d \bar{r}\left(\left(\frac{\partial \bar{V}}{\partial \bar{r}}\right)^{2}+\left(\frac{\partial \bar{V}}{\partial \theta}\right)^{2}\right) .
$$

Optimal values for the particle concentration have been found from the following conditions

$$
\frac{d \dot{S}}{d \varphi}=0, \quad \frac{d^{2} \dot{S}}{d \varphi^{2}}>0 .
$$

Numerical solutions of the corresponding transcendental equation (19) have been found for different sets of material parameters, external magnetic field ( $\mathrm{H}$ number) and flow regime (Reynolds number $\operatorname{Re}=\rho_{f} V_{0} R / \mu_{f}$ ).

4. Results and discussion. At the first stage of the study, the obtained results have been compared to similar ones computed in [9] with non-slip BC. The same material parameters and values $\mathrm{Re}, \mathrm{H}$ have been used. The velocity profiles at different angular coordinates $\theta$ are presented in Fig.2a,b. In the velocity slip $\mathrm{BC}$ noticeable flow acceleration near the wall due to the Knudsen layer is observed.

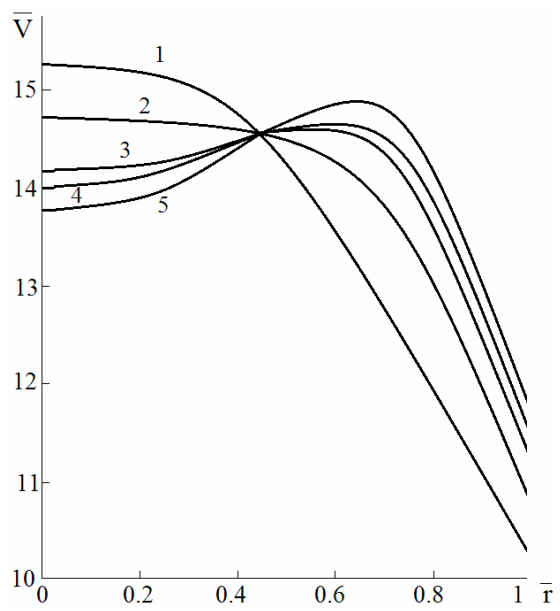


a

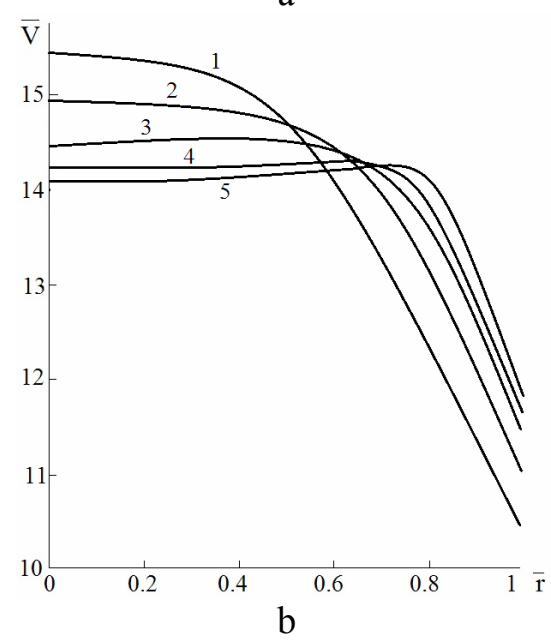

Fig.2. Velocity profiles $\overline{\mathrm{V}}(\overline{\mathrm{r}})$ at $\theta=90^{\circ}$ (a) and $\theta=45^{\circ}$

(b) at $\mathrm{Re}=100, \mathrm{H}=500, \mathrm{~h} / \mathrm{R}=0.5, \varphi=5 \%$; the curves $1-5$ correspond to $\sigma_{\mathrm{w}} / \sigma_{\mathrm{f}}=0.1,1,10,100,1000$.

The flow is no axisymmetrical due to the magnetic field distribution; at low wall conductivity the profiles are close to the parabolic at any $\theta$ while at low relative conductivity of the wall the profiles are flattened (curves 2 in Fig.2a,b) that is proper to MHD flows in comparison with Poiseuille-type flows [8]. At high wall conductivity the M-shaped velocity profiles (curves 3-1 in Fig.2a,b) are developed. Similar results have been obtained in the rectangle ducts [8] and the circular tubes without slip [9]. The flow velocity at the wall always increases with $\alpha_{1,2}$ while the velocity at the axis is negligibly increased with $\alpha_{1}$, became more flattened at higher $\alpha_{2}$ and the maximal axial velocity at $0.5<\overline{\mathrm{r}}<0.8$ is smaller when $\alpha_{2}<0$ due to negative curvature of the flow profile in the Knudsen layer. At $\alpha_{1,2}=0$ all the profiles pass through a common point [9] (intersection points in Fig.2a,b) while when $\alpha_{1} \neq 0$ the intersection points could differ at some angles $\theta$ (Fig.2b).

The dependence of the non-dimensional pressure gradient $\quad \overline{\mathrm{P}}=\frac{\Delta \mathrm{P}(\mathrm{R}+\mathrm{h})^{2}}{\mu_{\mathrm{f}} \mathrm{LR}^{2} \mathrm{~V}_{0}} \quad$ on the relative wall thickness $\overline{\mathrm{h}}=\mathrm{h} / \mathrm{R}$ is presented in Fig.3. It is shown, the thick electrically conducting wall significantly influence the pressure drop needed for the steady flow of the micro/nanofluid with the same flow rate or the flow with the same wall shear stress that is the main factor of the entropy production (18). This conclusion corresponds to the computational results presented in [9] for the no-slip BC.

Such characteristic dependence $\overline{\mathrm{P}}(\overline{\mathrm{h}})$ gave already been founded for the MHD-flows between the parallel conducting and insulating thin plates, in the rectangular ducts with conducting and insulating walls, and in the circular ducts with thin and thick walls with arbitrary electrical conduction.

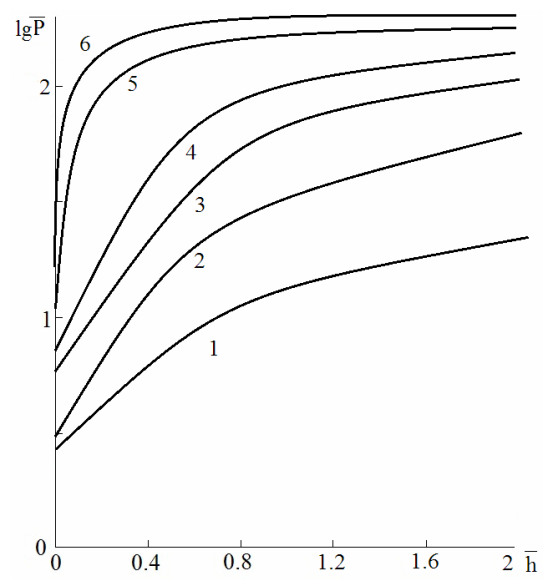

Fig. 3. Dependencies of the nondimensional pressure gradient of the wall thickhess; the curves 1-6 correspond to $\sigma_{\mathrm{w}} / \sigma_{\mathrm{f}}=100,10,5,1,0.5,0.1$; other parameters are the same as in Fig. 2.

The aim of this study is computation of the optimal concentration of the micro/nanoparticles in the suspension. As we can see from the Fig. 2-3, high concentration of the micro/nanoparticles increases the density, electric conductivity and other useful properties of the suspension for the heat/mass transfer abilities. As it is shown in Fig.2a,b, in this case the suspension in the presence of the external magnetic field will benefit in the flow acceleration in the core of the flow, but due to the lower flow gradients the rotational Magnus forces exerted onto the micro/nanoparticles will produce thinner wall layer free of particle [5].

5. Conclusions. Numerical computations on the detailed MHD flow model of the electrically conducting suspension of micro/nanoparticles through a circular tube with a wall of finite thickness and electric conductivity with the second order velocity slip BC proper to the micro- and nanofluids in comparison to the velocity non-slip BC accepted for convenient fluids, revealed significant differences in the velocity profiles, pressure gradients governing the fluid flow, the magnetic field distributions inside the fluid flow and the thick conducting/insulating wall. The most interesting results for the macrofluids with no-slip boundary conditions at the walls have been obtained before, but the same conditions for the micro/nanofluidics are still of a great interest in relation of numerous applied applications for the micro/nanosuspensions used for the purification and desalinization of natural waters, different biological fluids, environmental waters polluted by different microparticles and nanoparticles like bacteria, wastewaters, wicro/nano wastes, etc. 


\section{References}

1. Nanoscale Multifunctional Materials: Science and Applications, S.M. MUKHOPADHYAY (Ed.), Wiley, (2012).

2. MUSA S.M. (2015) Nanoscale Flow: Advances, Modeling, and Applications, CRC Press.

3. SHEIKHOLESLAMI M., GANJI D.F. (2016) External magnetic field effects on hydrothermal treatment of nanofluid, Elsevier.

4. KIZILOVA N. (2019) Electromagnetic Properties of Blood and Its Interaction with Electromagnetic Fields. In: Advances in Medicine and Biology. Vol.137. Ed. by L.V. Berhardt. NOVA Sci. Publ. p.1-74.

5. BATYUK L., KIZILOVA N. (2017) Modeling of laminar flow of the erythrocyte suspensions as Bingham fluids. Visnyk KNU, Ser. Physics and Mathematics Sciences. N4. p.23-28.

6. KANDLIKAR S. GARIMELLA S., LI D., COLIN S., KING M. (2005) Heat Transfer and Fluid Flow in Minichannels and Microchannels. Elsevier.

7. CHEREVKO V., KIZILOVA N. (2017) Complex flows of immiscible microfluids and nanofluids with velocity slip bounary conditions. Nanophysics, Nanomaterials, Interface Studies, and Applications, Springer Proceedings in Physics, vol. 183, O. Fesenko, L. Yatsenko (eds.). p. 207-230.

8. VATAZHYN A.B., LJUBIMOV G.A., REGIRER S.A. (1970) Magnetohydrodynamic flows in the channels. Moscow: Nauka. (in Russian)

9. Samad A. (1981) The flow of conducting fluids through circular pipes having finite conductivity and finite thickness under uniform transverse magnetic fields. International Journal of Engineering Sciences. Vol.19. p. 1221-1232.

\section{Список використаних джерел}

1. Nanoscale Multifunctional Materials: Science and Applications, S.M. Mukhopadhyay (Ed.), Wiley, 2012.

2. Musa S.M. Nanoscale Flow: Advances, Modeling, and Applications, CRC Press, 2015.

3. Sheikholeslami M., Ganji D.F. External magnetic field effects on hydrothermal treatment of nanofluid, Elsevier, 2016.

4. Kizilova N. Electromagnetic Properties of Blood and Its Interaction with Electromagnetic Fields. In: Advances in Medicine and Biology. Vol.137. Ed. by L.V. Berhardt. NOVA Sci. Publ. 2019, - P.1-74.

5. Батюк Л. В., Кізілова Н. М. Моделювання ламінарних течій суспензій еритроцитів крові як бінгамівських мікрорідин. // Вісник КНУ імені Т.Г.Шевченко. Серія «Фізикоматематичні науки». - 2017. - №4. - С.23-28.

6. Kandlikar S. Garimella S., Li D., Colin S., King M. Heat Transfer and Fluid Flow in Minichannels and Microchannels. Elsevier, 2005.

7. Cherevko V., Kizilova N. Complex flows of immiscible microfluids and nanofluids with velocity slip bounary conditions. // Nanophysics, Nanomaterials, Interface Studies, and Applications, Springer Proceedings in Physics, vol. 183, O. Fesenko, L. Yatsenko (eds.). - 2017. - P. 207-230.

8. Ватажин А.Б., Любімов Г.О., Регірер С.О. Магнітогідродинамічні течії в каналах. Москва:Наука. - 1970. (рос. мовою).

9. Samad A. The flow of conducting fluids through circular pipes having finite conductivity and finite thickness under uniform transverse magnetic fields. // International Journal of Engineering Sciences. - 1981. - Vol.19. - P. 1221-1232.

Надійшла до редколегії 05.11.2019 